\title{
Analysing the importance rating of CSR challenges in order to improve the supply chain performance
}

\section{Mohit Tyagi*, Pradeep Kumar and Dinesh Kumar}

Department of Mechanical and Industrial Engineering, Indian Institute of Technology Roorkee,

Roorkee 247667, Uttarakhand, India

Email: mohitmied@gmail.com

Email: kumarfme@iitr.ernet.in

Email: dinesfme@iitr.ernet.in

*Corresponding author

\begin{abstract}
To achieve a high reputation, in the competitive market place, organisations are trying to implement CSR strategies along with their supply chain business functions. The objective of this research is to identify and analyse the significant CSR challenges with an aim to improve the SCP of automobile industry located at NCR of India. To achieve the objective, seven CSR challenges have been considered and analysed using preference rating approach. In order to make analyses more robust, a decision-making trial and evaluation laboratory (DEMATEL) approach has also been used to suggest implementable strategies for improvements in SCP. The results indicate that the CSR challenge 'narrow perception towards CSR initiatives' holds first rank through achieving highest importance rating (1.0000), highest prominence (6.3194) and highest relation (1.0834) value, among other considered challenges. The findings of this research may help mangers in CSR based decisions-making processes for improving the SCP of their organisation.
\end{abstract}

Keywords: corporate social responsibility; CSR challenges; preference rating approach; DEMATEL approach.

Reference to this paper should be made as follows: Tyagi, M., Kumar, P. and Kumar, D. (2014) 'Analysing the importance rating of CSR challenges in order to improve the supply chain performance', Int. J. Intercultural Information Management, Vol. 4, No. 1, pp.34-50.

Biographical notes: Mohit Tyagi is a Research Scholar in the Department of Mechanical and Industrial Engineering, IIT Roorkee, India. He has obtained his bachelor's degree (Hons) in Mechanical Engineering from Uttar Pradesh Technical University, Lucknow, India, in 2008 and the master's degree in Mechanical Engineering with specialisation in Product Design and Development (gold medallist) from Motilal Nehru National Institute of Technology, Allahabad, India, in 2010. His area of research is supply chain management.

Pradeep Kumar is a Professor in the Department of Mechanical and Industrial Engineering, IIT Roorkee, India. He obtained his bachelor's degree in Industrial Engineering in 1982, master's degree in Production Engineering (gold medallist) in 1989, and $\mathrm{PhD}$ degree in 1994 with specialisation in 
Industrial Engineering all from the University of Roorkee (now IIT Roorkee), India. He has more than 25 years' research/teaching experience. He has supervised $27 \mathrm{PhD}$ theses and had contributed more than 450 publications in international/national journals/conferences of repute. His research interests include advanced manufacturing processes, microwave joining of metals, metal casting, industrial engineering, Supply Chain Management (SCM) and quality engineering: robust design methodologies and reliability engineering.

Dinesh Kumar is a Professor in the Department of Mechanical and Industrial Engineering, IIT Roorkee, India. He completed BSc in Engineering with honours (Mechanical engineering) in 1980 from Punjab University and MSc in Mechanical Engineering from the University of Roorkee in 1984. He received the PhD degree in 1991 in Mechanical Engineering from the University of Roorkee, India. He has about 25 years of research/teaching and industrial experience and more than 150 publications in international/national journals/ conferences. He has guided a number of students for their undergraduate projects, master's dissertations and $\mathrm{PhD}$ degrees. His fields of interests are system behaviour in industry, maintenance engineering, reliability analysis and industrial engineering.

This paper is a revised and expanded version of a paper entitled 'Modelling of CSR challenges in aspect of improving the supply chain performance' presented at the 'International Conference on Management and Business Innovations (ICOMBI) 2013', MNIT Jaipur, India, 5-6 April 2013.

\section{Introduction and background}

In the last decade, the field of Corporate Social Responsibility (CSR) has been displayed as a key enabler to enlarge the view of responsibilities of business to integrate the environment, local communities, employment practices and ethics in business practices, human rights, the marketplace and the workplace. The market and social demand is increasing for transparency and growing expectations that corporations measure, report and continuously improve their social, environmental and economic performance. CSR emphasises more attention of firm's responsibilities towards the social and environmental practices, instead of only on legal and economic concerns. For successful implementation of CSR activities, it is necessary that the CSR principles become an integral part of the corporation's values and strategic planning. For the implementation of sustainable SCM principles, it is required by the company to comprehend responsibility about the impact of their social and environmental issues along the supply chain.

CSR is seen as an inclusive set of policies, practices and programmes that are integrated into business operations, supply chains and decision-making processes throughout all the functions of the company. There are various existing definitions of CSR; some of them are as follows: McWilliams and Siegel (2000) define CSR as "actions that appear to further some social good, beyond the interest of the firm and that which is required by law". Jamali and Mirshak (2007) defined CSR as a set of management practices that have a positive impact of operations on society by improving the firm profit. According to Business for Social Responsibility (BSR), CSR is described 
as "achieving commercial success in ways that honor ethical values and respect people, communities, and the natural environment". Vicianova (2011) says that CSR works as a commitment to improve community welfare by discretionary business practices and contributions of the corporate. CSR is a theme attracting worldwide attention to attain a new image in the global economy (Jamali et al., 2008).

The notion of CSR is a form of management that maintains ethical relationship and transparency of the company with all the stakeholders and establishes a good relationship to achieve corporate goals. It is clear that company's activities have a direct impact on the communities with which they are working. A company can obtain competitive benefits through running socially responsible activities, which require that CSR activities be connected with corporate strategies. The finding of these activities adds a better value to the products in the eyes of the public and also improves the local business environment (Porter and Kramer, 2002).

Porter and Kramer (2006) discuss the various issues of existence of the interdependence between corporations and local society. Husted and Salazar (2006) examined CSR strategies in firms with the objective of maximising both profits and social performance. According to Carroll (1999), the concept of CSR can be viewed as a multidimensional structure and has four important dimensions, namely economic, legal, ethical and discretionary. To improve the societal perspective, it is required to integrate the basic research (in order to develop intangible tools and mechanism) with the future research on CSR; it will change the organisational behaviour (Lee, 2008). Christmann (2004) says that high pressure from government and non-government agencies on all organisations contribute to the adoption of ISO 9000 and ISO 14000 standards to meet the high-quality performance and operational environmental strategies.

To develop, implement, improve and maintain a social responsibility erection among the business organisations, International Organization for Standardization (ISO) has launched a standard, namely ISO 26000, which emphasises on accountability, transparency, operational performance and customer satisfaction, and also visualises the important guidelines to scrutinise social responsible behaviour and relationship among organisations, stakeholders and society. ISO 26000 has an important feature: it does not contain any requirement during certification, because it works as a charitable guide for all organisations; this feature distinguishes ISO 26000 (for social responsibilities) from ISO 9000 (for quality) and ISO 14000 (for environment). Castka and Balzarova (2008) discussed various propositions about diffusion of ISO 26000 and its benefits in improving the supply chain performance among organisations. Fuzi et al. (2013) proposed a model to examine the relationship among CSR practices, ISO 26000 and CSR performance by considering a case of the Malaysian automotive industry. Magnan et al. (2011) analysed the role of supplier code of conducts or CSR on SCP and the reputation of an organisation.

According to Yilmaz (2008), CSR practice should be structured in such a way that the organisation is responsible for the impact on employees, customers, communities and the operational environment. Besides the benefits, CSR also affects the society more than the company and its shareholder (Vicianova, 2011). Spena and De Chiara (2012) analysed the interaction between CSR innovation and supply chain management in the relational context and found that CSR should be integrated with supply chain functions to 
improve firm performance. Whatling et al. (2010) investigated the role of corporate responsibility reporting in handling and broadcasting in biodiversity of supply chain issues of an organisation. Basheka and Serugo (2011) examined the effect of CSR initiatives on the evolution of local communities considering the downstream supply chain of Mobile Telephone Networks (MTN) in Uganda. Risso (2012) focused on the international supply chains of large companies in specific sectors to control over their suppliers by implementing CSR initiatives.

Afonso et al. (2012) found that CSR has a positive relationship with social performance. Tsiakis (2009) analysed the social responsible behaviour of businesses by applying the CSR thought on the information security management. Mishra (2012) investigated the influence of CSR on consumer behaviour through emphasising the consumer awareness about CSR activities and socially responsible nature towards purchasing of goods. Knudsen (2013) carried out a comparison between CSR initiatives and human resource management activities in the context of gender diversity by considering the case of US multinational corporations. Gelbmann (2010) carried out a comparison between two CSR tools for small and medium-sized enterprises. Bhattacharyya (2010) developed a scale which helps the managers in managing strategic CSRs.

Based on the above discussion, to endure in this competitive environment, the organisations are looking forward to identify and understand CSR challenges/barriers that may create a hindrance in the supply chain performance of the organisations. The objective of this research is to identify and analyse the significant CSR challenges with an aim to improve the SCP of the automobile industry located in the National Capital Region (NCR) of India. To achieve the objective, seven CSR challenges have been considered and analysed using the preference rating approach. In order to make the analyses more robust, a Decision-Making Trial and Evaluation Laboratory (DEMATEL) approach has also been used to suggest implementable strategies for improvements in SCP.

\section{Problem description}

The automobile sector is growing very rapidly in the Indian market and as a result every manufacturer is looking to develop a competitive edge to capture more in the market. From a survey conducted by BusinessLine (http://www.thehindubusinessline.com), it was found that the Indian automobile industries are viewing towards improving their SCP to maintain a good reputation and stability in the competitive environment. Limited studies, towards improving the SCP of the Indian automobile industry, have been reported (Saad and Patel, 2006). As discussed earlier, CSR is becoming a proactive theme for implementation with supply chain functions of an organisation. Based on this, the present study has been performed on automobile industries located in the NCR of India. In this study, seven significant CSR challenges have been identified and considered for further analysis. CSR challenges have been identified on the basis of the available literature and after subsequent discussions with field experts. The CSR challenges and their respective explanations are given in Table 1. 
Table 1 List of CSR challenges

\begin{tabular}{|c|c|c|c|}
\hline S. No. & CSR challenges & Explanation & References \\
\hline 1 & $\begin{array}{l}\text { Lack of awareness } \\
\text { of general public in } \\
\text { CSR activities }\end{array}$ & $\begin{array}{l}\text { It has been seen that most of the public } \\
\text { is unaware about the role of CSR } \\
\text { activities of companies. The reason for } \\
\text { this is no knowledge about CSR } \\
\text { activities and lack of communication } \\
\text { among the companies in order to } \\
\text { improve the CSR activities. }\end{array}$ & $\begin{array}{l}\text { Khanna and Gupta (2011), } \\
\text { Heslin and Ochoa (2008), } \\
\text { Gunningham (2009), } \\
\text { Svendsen et al. (2001), } \\
\text { Loureiro et al. (2012), } \\
\text { Azevedo et al. (2013) }\end{array}$ \\
\hline 2 & $\begin{array}{l}\text { Lack of } \\
\text { transparency }\end{array}$ & $\begin{array}{l}\text { In the context of CSR, lack of } \\
\text { transparency is one of the significant } \\
\text { challenges for the corporate business } \\
\text { among the Small and Medium Size } \\
\text { Enterprises (SMEs). It also reduces the } \\
\text { level of trust among the companies, } \\
\text { which is very essential for CSR } \\
\text { initiative. }\end{array}$ & $\begin{array}{l}\text { Boyd et al. (2007), } \\
\text { Fukukawa and Teramoto } \\
\text { (2009), Khanna and Gupta } \\
\text { (2011), Sardinha et al. } \\
\text { (2011) }\end{array}$ \\
\hline 3 & $\begin{array}{l}\text { Non-availability of } \\
\text { well-organised } \\
\text { non-governmental } \\
\text { organisation }\end{array}$ & $\begin{array}{l}\text { Lack of well-organised non- } \\
\text { governmental organisations in remote } \\
\text { and rural areas creates a problem in the } \\
\text { identification of real needs of the public. } \\
\text { Therefore, the implementation of CSR } \\
\text { activities is becoming difficult. }\end{array}$ & $\begin{array}{l}\text { Maloni and Brown (2006), } \\
\text { Seuring and Müller (2008), } \\
\text { Khanna and Gupta (2011), } \\
\text { Ciliberti et al. (2011) }\end{array}$ \\
\hline 4 & $\begin{array}{l}\text { Narrow perception } \\
\text { towards CSR } \\
\text { initiatives }\end{array}$ & $\begin{array}{l}\text { It has been realised that, usually, } \\
\text { government agencies and non- } \\
\text { governmental organisations have a } \\
\text { narrow perception towards the CSR } \\
\text { initiatives. That is why corporates are } \\
\text { mostly confused about participating in } \\
\text { such activities for a medium or long } \\
\text { period. }\end{array}$ & $\begin{array}{l}\text { Murillo and Lozano (2006), } \\
\text { Ciliberti et al. (2008), Font } \\
\text { et al. (2012), Khanna and } \\
\text { Gupta (2011) }\end{array}$ \\
\hline 5 & $\begin{array}{l}\text { Non-availability of } \\
\text { clear CSR } \\
\text { guidelines }\end{array}$ & $\begin{array}{l}\text { Non-availability of clear guidelines } \\
\text { creates a hindrance during CSR } \\
\text { initiatives. There should be some } \\
\text { standard policies or guidelines for the } \\
\text { companies on the basis of their business } \\
\text { profile, to provide a complete direction } \\
\text { to CSR initiatives. }\end{array}$ & $\begin{array}{l}\text { Boyd et al. (2007), Sardinha } \\
\text { et al. (2011), Khanna and } \\
\text { Gupta (2011), Valiente et } \\
\text { al. (2012) }\end{array}$ \\
\hline 6 & $\begin{array}{l}\text { Lack of consensus } \\
\text { on implementing } \\
\text { CSR issues }\end{array}$ & $\begin{array}{l}\text { This lack of consensus often results in } \\
\text { replication of activities by corporates in } \\
\text { areas of their involvement. This factor } \\
\text { bounds companies' capabilities to } \\
\text { commence impact assessment of their } \\
\text { initiatives in a timely manner. }\end{array}$ & $\begin{array}{l}\text { Fuzi et al. (2013), Tsiakis } \\
\text { (2009), Luo and } \\
\text { Bhattacharya (2006), } \\
\text { Lindgreen et al. (2009), } \\
\text { Khanna and Gupta (2011) }\end{array}$ \\
\hline 7 & $\begin{array}{l}\text { Lack of thinking } \\
\text { towards } \\
\text { environmental } \\
\text { protection }\end{array}$ & $\begin{array}{l}\text { During these days, governmental/non- } \\
\text { governmental agencies are forcing the } \\
\text { companies to make green supply chain } \\
\text { in order to achieve a pollution-free } \\
\text { environment. For this, appropriate } \\
\text { thinking towards environmental } \\
\text { protection is very essential to improve } \\
\text { the supply chain performance in the } \\
\text { context of CSR. }\end{array}$ & $\begin{array}{l}\text { Chapple et al. (2005), } \\
\text { Khanna and Gupta (2011), } \\
\text { Ageron et al. (2012) }\end{array}$ \\
\hline
\end{tabular}


To meet the objectives of the present research, a questionnaire has been formulated using a five-point Likert scale (ranging from 1 for very least influence to 5 for very high influence). In total, 54 responses out of 159 field experts were received (response rate of $34 \%$ ) and the percentage response rate is sufficient to drive the analysis (Malhotra and Grover, 1998). Many meetings have also been arranged with the experts to know the contextual relationship between the considered challenges. After collecting the data, reliability analysis was done by calculating the Cronbach $\alpha$ coefficient, using SPSS software, which was found to be 0.790 , which is under the recommended range: $0.7<\alpha$ $<0.95$.

\section{Preference rating approach: numerical illustration}

In the present paper, an attempt is made to illustrate the interactions between the various challenges of CSR by using a new rating method, called the Company Preference Rating (CPR) method, developed by Nahm et al. (2013). This method determines the Relative Importance Rating (RIR) of the CSR barriers very efficiently. A graph theory-based representation technique, to model human's incomplete or uncertain preference structure, called the Preference Graph (PG) (Nahm and Ishikawa, 2005; Nahm and Ishikawa, 2006) has also been proposed.

The PG representations are used to collect the company's incomplete/uncertain views on the relative importance of the challenges/issues/barriers. There are various existing methods of decision-making, such as AHP, ANP, fuzzy AHP, fuzzy ANP, TOPSIS and fuzzy TOPSIS. In all these methods, pair-wise comparisons of all the pairs of parameters are required. The CPR method enables each company to make comparisons between their issues and then analyse their preference graphs to determine the RIRs of the existing issues.

PG representations of the company's preferences on the challenges are given in Figure 1. During this study, seven challenges, based on the literature and industry experts' opinions, were identified. The data were collected from four selected companies.

These four companies are denoted as $C P_{1}, C P_{2}, C P_{3}$ and $C P_{4}$ and the seven challenges are denoted as $C_{1}, C_{2}, C_{3}, C_{4}, C_{5}, C_{6}$ and $C_{7}$ ( $C_{1}$ for 'lack of awareness of local public in CSR activities', $C_{2}$ for 'lack of transparency', $C_{3}$ for 'non-availability of wellorganised non-governmental organisations', $C_{4}$ for 'narrow perception towards CSR initiatives', $C_{5}$ for 'non-availability of clear CSR guidelines', $C_{6}$ for 'lack of consensus on implementing CSR issues' and $C_{7}$ for 'lack of thinking towards environmental protection'). Preference graphs, represented by four companies, have been denoted as $P G_{1}, P G_{2}, P G_{3}$ and $P G_{4}$, as shown in Figure 1 .

Consider a set of $n$ companies; $C P_{n}$ represents a preference graph. Then, let $P G_{n}$ be an adjacency matrix for the PG and let $M$ be a positive integer. Then, the entry $p g_{i j}$ $(i, j=1,2, \ldots, m, \ldots, M)$ of $P G_{n}^{M}$ gives the number of $M$ stage dominances of $i$ over $j$, i.e. the dominance the matrix $D^{n}$ is

$$
D^{n}=P G_{n}^{1}+P G_{n}^{2}+\ldots P G_{n}^{m} \ldots+P G_{n}^{M}
$$

The sum of the entries $\left(d_{m}^{n}\right)$ in row $m$ of the dominance matrix means the total number of ways that $m$ is dominant to $1,2, \ldots, M$ stages (Lial et al., 2002). In this study, $(M-1)$ 
stage dominances are considered for the PG. In the present case, seven challenges are considered, which means five dominance stages exist. The adjacency matrix of $P G_{1}$ can be represented as

$$
P G_{1}^{1}=\left[\begin{array}{ccccccc}
0 & 0 & 1 & 0 & 0 & 0 & 0 \\
0 & 0 & 0 & 0 & 0 & 0 & 0 \\
0 & 0 & 0 & 0 & 0 & 0 & 0 \\
0 & 0 & 0 & 0 & 1 & 0 & 1 \\
0 & 0 & 0 & 0 & 0 & 1 & 1 \\
0 & 1 & 0 & 0 & 0 & 0 & 0 \\
1 & 0 & 0 & 0 & 0 & 0 & 0
\end{array}\right]
$$

Figure 1 Representation of relative importance of issues using Preference Graph (PG)

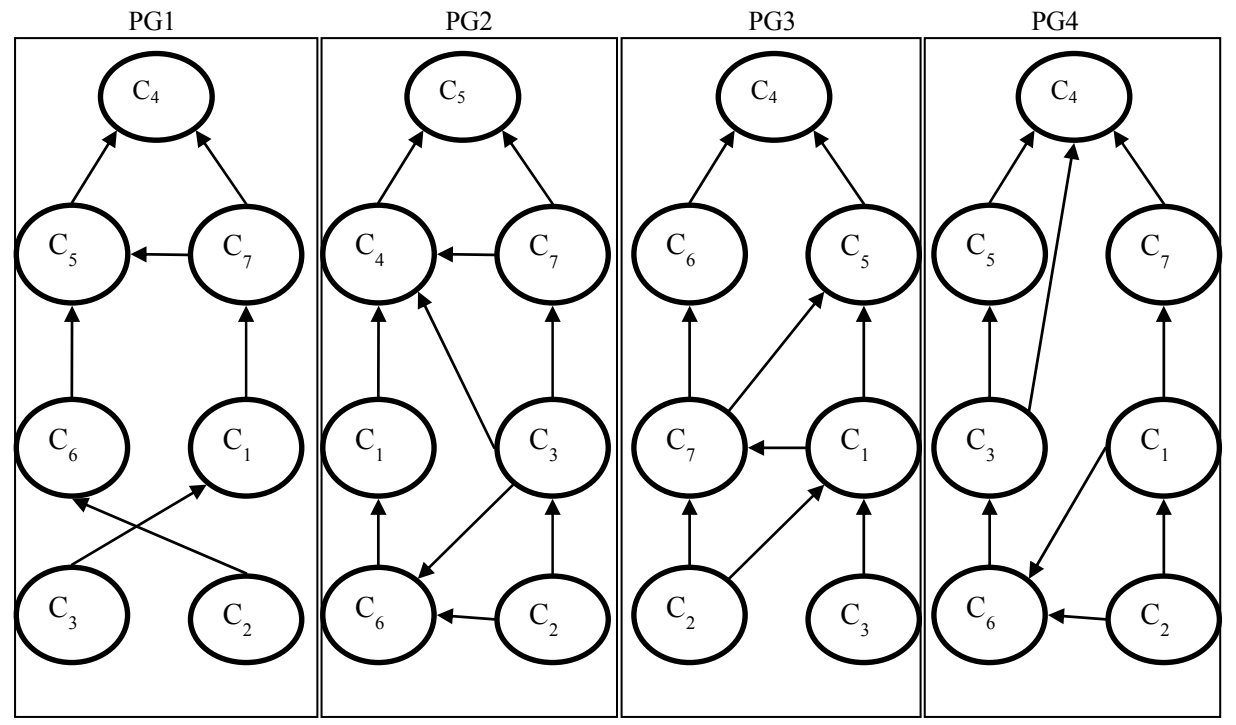

In the case with $M=6$, the dominance matrix $\left(D^{1}\right)$ of $P G_{1}$ can be computed using the following equation:

$$
D^{1}=P G_{1}^{1}+P G_{1}^{2}+P G_{1}^{3}+P G_{1}^{4}+P G_{1}^{5}+P G_{1}^{6}
$$

Using equation (3), $D^{1}$ of $P G_{1}$ is obtained as

$$
D^{1}=\left[\begin{array}{lllllll}
0 & 0 & 1 & 0 & 0 & 0 & 0 \\
0 & 0 & 0 & 0 & 0 & 0 & 0 \\
0 & 0 & 0 & 0 & 0 & 0 & 0 \\
2 & 1 & 2 & 0 & 1 & 1 & 2 \\
1 & 1 & 1 & 0 & 0 & 1 & 1 \\
0 & 1 & 0 & 0 & 0 & 0 & 0 \\
1 & 0 & 1 & 0 & 0 & 0 & 0
\end{array}\right]
$$


From equation (4), $d_{1}^{1}=1, d_{2}^{1}=0, d_{3}^{1}=0, d_{4}^{1}=9, d_{5}^{1}=5, d_{6}^{1}=1$ and $d_{7}^{1}=1$. In other words, challenge $C_{1}$ is dominated in $0+0+1+0+0+0+0=1$ way, $C_{5}$ is dominated in five ways, $C_{7}$ in two ways and similarly for others. Repeat the following above computation procedure for $P G_{2}, P G_{3}$ and $P G_{4}$ accordingly.

Dominance matrix $\left(D^{2}\right)$ of $P G_{2}$ can be computed by:

$$
D^{2}=P G_{2}^{1}+P G_{2}^{2}+P G_{2}^{3}+P G_{2}^{4}+P G_{2}^{5}+P G_{2}^{6}
$$

Using equation (5), $D^{2}$ of $P G_{2}$ is obtained as

$$
D^{2}=\left[\begin{array}{lllllll}
0 & 1 & 1 & 0 & 0 & 1 & 0 \\
0 & 0 & 0 & 0 & 0 & 0 & 0 \\
0 & 1 & 0 & 0 & 0 & 0 & 0 \\
1 & 4 & 3 & 0 & 0 & 1 & 1 \\
1 & 5 & 4 & 1 & 0 & 1 & 2 \\
0 & 2 & 1 & 0 & 0 & 0 & 0 \\
0 & 1 & 1 & 0 & 0 & 0 & 0
\end{array}\right]
$$

From equation (6), $d_{1}^{2}=3, d_{2}^{2}=0, d_{3}^{2}=1, d_{4}^{2}=10, d_{5}^{2}=14, d_{6}^{2}=3$ and $d_{7}^{2}=2$. Similarly, for $P G_{3}$, we obtained $d_{1}^{3}=2, d_{2}^{3}=0, d_{3}^{3}=0, d_{4}^{3}=12, d_{5}^{3}=8, d_{6}^{3}=5$ and $d_{7}^{3}=4$. For $P G_{4}$, the sum of the entries can be given as $d_{1}^{4}=1, d_{2}^{4}=0, d_{3}^{4}=4$, $d_{4}^{4}=14, d_{5}^{4}=5, d_{6}^{4}=3$ and $d_{7}^{4}=2$.

The Relative Degree of Preference (RDP) of each company ( $n$ ) can be obtained by the following expression; the maximum value is 1 :

$$
r d p_{m}^{n}=\frac{\left(1+d_{m}^{n}\right)}{\max _{m=1 \ldots . . M}\left(1+d_{m}^{n}\right)}, \quad n=1 \ldots \ldots N
$$

For the illustrative convenience, let us denote the RDP of each company $(n)$ as a vector:

$$
R D P_{n}=\left(r d p_{1}^{n}, r d p_{2}^{n}, \ldots r d p_{m}^{n}, \ldots r d p_{M}^{n}\right)
$$

The RDP for $P G_{1}, P G_{2}, P G_{3}$ and $P G_{4}$ are as follows:

$$
\left.\begin{array}{l}
R D P_{1}=\left(\frac{2}{10}, \frac{1}{10}, \frac{1}{10}, \frac{10}{10}, \frac{6}{10}, \frac{2}{10}, \frac{3}{10}\right) \\
R D P_{2}=\left(\frac{4}{15}, \frac{1}{15}, \frac{2}{15}, \frac{11}{15}, \frac{15}{15}, \frac{4}{15}, \frac{3}{15}\right) \\
R D P_{3}=\left(\frac{3}{13}, \frac{1}{13}, \frac{1}{13}, \frac{13}{13}, \frac{9}{13}, \frac{6}{13}, \frac{5}{13}\right) \\
R D P_{4}=\left(\frac{2}{15}, \frac{1}{15}, \frac{5}{15}, \frac{15}{15}, \frac{6}{15}, \frac{4}{15}, \frac{3}{15}\right)
\end{array}\right\}
$$


Based on the RDP of each company, the RIRs of the issues can be obtained. Since $K$ companies are taken into account, the RIR of each issue is determined by the following normalisation (to be the maximum of 1 ), and its vector expression can be denoted as

$$
\begin{aligned}
r i r_{m} & =\frac{\sum_{m=1}^{N} r d p_{m}^{n}}{\max \left(\sum_{n=1 \ldots . \ldots M}^{N} r d p_{m}^{n}\right)} \\
R I R & =\left(\operatorname{rir}_{1}, \operatorname{rir}_{2}, \ldots, \operatorname{rir}_{m}, \ldots \ldots, \operatorname{rir}_{M}\right)
\end{aligned}
$$

The value of the denominator of equation (10) is 3.7334. The RIRs for existing issues are calculated and are given as follows:

$$
R I R=(0.2225,0.0830,0.1723,1.0000,0.7211,0.3200,0.2905)
$$

From equation (12), the importance ranking of the considered CSR challenges can be decided as: $C_{4}>C_{5}>C_{6}>C_{7}>C_{1}>C_{3}>C_{2}$, by using the CPR approach. Hence, it is clear that the 'narrow perception towards CSR initiatives' $\left(C_{4}\right)$ is with the highest importance rating. In order to make the findings more robust, the DEMATEL approach has been applied to check the validity or robustness of the obtained ranking to analyse the CSR challenges based on their existence under cause and effect groups.

\section{Validation of importance rating through DEMATEL approach}

To study and decompose the complex problems, the DEMATEL method was developed by the Science and Human Affairs Program of the Battelle Memorial Institute of Geneva between 1972 and 1976 (Tzeng et al., 2007; Wu, 2008). The step-by-step algorithm of the DEMATEL method (modified from Tzeng et al., 2007) is given as:

Step 1: Compute average direct relation matrix. Each expert/respondent was asked to evaluate the direct influence of $i$ th criteria over the $j$ th criteria on a scale of 0 (no influence), 1 (low influence), 2 (high influence), and 3 (very high influence). The notation of $x_{i j}$ indicates the degree to which the respondent believes factor $i$ affects factor $j$.

For $i=j$, the diagonal elements are set to zero. For each respondent, a nonnegative matrix can be given as

$$
X^{p}=\left[x_{i j}^{p}\right]_{n \times n}
$$

where $p$ is the number of respondents and lies between 1 and $m(1 \leq p \leq m)$. To summarise the all opinions of ' $m$ ' respondents/decision-makers, average direct relation matrix $A=\left[a_{i j}\right]$ can be obtained as

$$
a_{i j}=\frac{1}{m} \sum_{p=1}^{m} x_{i j}^{p}
$$


Step 2: Calculate the normalised direct relation matrix ' $X$ '. Normalisation is made by using the following equations:

$$
\begin{aligned}
& X=K \times A \\
& K=\frac{1}{\sum_{1 \leq i \leq n}^{\max } \sum_{j=1}^{n} a_{i j}}, i, j=1,2, \ldots \ldots, n
\end{aligned}
$$

Step 3: Calculate the total relation matrix ' $T$ '. This matrix can be obtained as

$$
T=X(I-X)^{-1}
$$

where ' $I$ ' is the identity matrix.

Step 4: Development of cause diagram. For this, the sum of rows and the sum of columns of the total relation matrix ' $T$ ' are calculated and denoted by ' $D$ ' and ' $R$ ', respectively. Then, we add the values of $D$ to $R,(D+R)$, called 'prominence', which discloses the relative importance of each criterion and is marked on the horizontal axis. Similarly, we have $(D-R)$ values, called as 'relation', which provide a categorisation of criteria in cause and effect groups. If $(D-R)$ is positive, then that criterion will lie in the cause group and if the $(D-R)$ is negative, then that criterion will fall under the effect group.

Finally, the cause diagram is obtained by mapping the data set of $(D+R$, $D-R$ ); based on this diagram, some insights are observed to make decisions:

$$
\begin{aligned}
& T=\left[t_{i j}\right]_{n \times n}, \quad i, j=1,2 \ldots, n \\
& D=\left[\sum_{j=1}^{n} t_{i j}\right]_{n \times 1}=\left[t_{i}\right]_{n \times 1} \\
& R=\left[\sum_{j=1}^{n} t_{i j}\right]_{1 \times n}=\left[t_{j}\right]_{1 \times n}
\end{aligned}
$$

The numerical illustration using the DEMATEL approach has been performed as: first of all, opinions of field experts have been collected to evaluate the direct influence of one challenge over the other on a scale of 0 (no influence), 1 (low influence), 2 (high influence) and 3 (very high influence). Then, using equation (14), the individual inputs were aggregated and an average direct-relation matrix, as shown Table 2, was obtained. The normalised direct-relation matrix, as shown in Table 3, has been computed using equations (15) and (16). Using equation (17), the total-relation matrix was obtained and is shown in Table 4. The sum of rows and the sum of columns of total-relation matrix were determined and the values of prominence or $(D+R)$ and relation or $(D-R)$, as given in Table 5, were obtained. By mapping $(D+R)$ and $(D-R)$ values, a cause diagram is constructed as shown in Figure 2. 
Table 2 Average direct relation matrix

\begin{tabular}{cccccccc}
\hline & $C_{1}$ & $C_{2}$ & $C_{3}$ & $C_{4}$ & $C_{5}$ & $C_{6}$ & $C_{7}$ \\
\hline$C_{1}$ & 0.0000 & 1.6250 & 2.0000 & 1.8750 & 1.5000 & 1.7500 & 1.7500 \\
$C_{2}$ & 1.0000 & 0.0000 & 1.0000 & 1.2500 & 1.3750 & 1.5000 & 1.0000 \\
$C_{3}$ & 2.1250 & 1.6250 & 0.0000 & 1.3750 & 1.3750 & 1.1250 & 1.6250 \\
$C_{4}$ & 2.6250 & 2.3750 & 2.5000 & 0.0000 & 2.6250 & 2.8750 & 2.6250 \\
$C_{5}$ & 2.5000 & 2.5000 & 2.6250 & 2.6250 & 0.0000 & 2.2500 & 1.8750 \\
$C_{6}$ & 1.6250 & 2.0000 & 2.3750 & 2.2500 & 2.2500 & 0.0000 & 2.3750 \\
$C_{7}$ & 2.2500 & 2.0000 & 1.5000 & 1.2500 & 2.1250 & 2.3750 & 0.0000 \\
\hline
\end{tabular}

Table 3 Normalised direct relation matrix

\begin{tabular}{cccccccc}
\hline & $C_{1}$ & $C_{2}$ & $C_{3}$ & $C_{4}$ & $C_{5}$ & $C_{6}$ & $C_{7}$ \\
\hline$C_{1}$ & 0.0000 & 0.1040 & 0.1280 & 0.1200 & 0.0960 & 0.1120 & 0.1120 \\
$C_{2}$ & 0.0640 & 0.0000 & 0.0640 & 0.0800 & 0.0880 & 0.0960 & 0.0640 \\
$C_{3}$ & 0.1360 & 0.1040 & 0.0000 & 0.0880 & 0.0880 & 0.0720 & 0.1040 \\
$C_{4}$ & 0.1680 & 0.1520 & 0.1600 & 0.0000 & 0.1680 & 0.1840 & 0.1680 \\
$C_{5}$ & 0.1600 & 0.1600 & 0.1680 & 0.1680 & 0.0000 & 0.1440 & 0.1200 \\
$C_{6}$ & 0.1040 & 0.1280 & 0.1520 & 0.1440 & 0.1440 & 0.0000 & 0.1520 \\
$C_{7}$ & 0.1440 & 0.1280 & 0.0960 & 0.0800 & 0.1360 & 0.1520 & 0.0000 \\
\hline
\end{tabular}

Table 4 Total relation matrix

\begin{tabular}{cccccccc}
\hline & $C_{1}$ & $C_{2}$ & $C_{3}$ & $C_{4}$ & $C_{5}$ & $C_{6}$ & $C_{7}$ \\
\hline$C_{1}$ & 0.2954 & 0.3896 & 0.4065 & 0.3698 & 0.3640 & 0.3896 & 0.3773 \\
$C_{2}$ & 0.2706 & 0.2113 & 0.2703 & 0.2628 & 0.2779 & 0.2936 & 0.2581 \\
$C_{3}$ & 0.3791 & 0.3531 & 0.2562 & 0.3116 & 0.3223 & 0.3216 & 0.3356 \\
$C_{4}$ & 0.5656 & 0.5542 & 0.5570 & 0.3769 & 0.5388 & 0.5696 & 0.5393 \\
$C_{5}$ & 0.5275 & 0.5283 & 0.5314 & 0.4921 & 0.3637 & 0.5066 & 0.4715 \\
$C_{6}$ & 0.4518 & 0.4709 & 0.4860 & 0.4435 & 0.4598 & 0.3495 & 0.4661 \\
$C_{7}$ & 0.4432 & 0.4328 & 0.4044 & 0.3613 & 0.4174 & 0.4441 & 0.2977 \\
\hline
\end{tabular}

Figure 2 Casual diagram (see online version for colours)

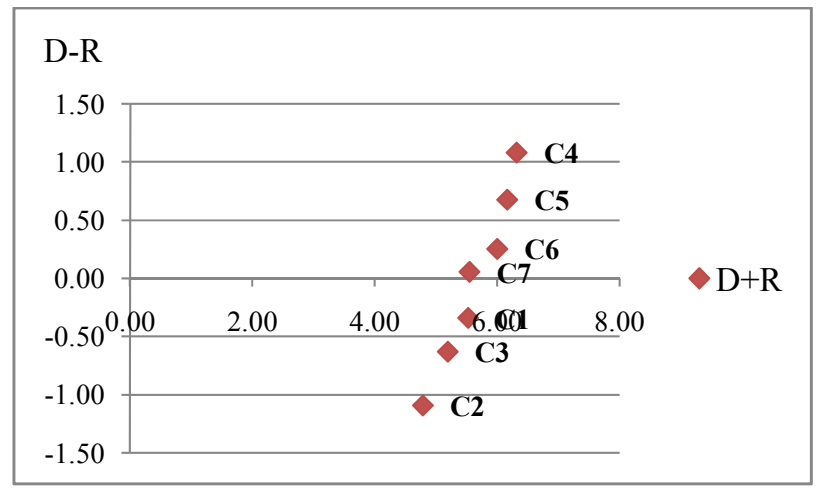




\section{Results}

The summary of the RIR of challenges based on the preference rating approach is given in equation (12) and its graphical visualisation is shown in Figure 3. From Figure 3, it is clear that the challenge ' $C_{4}$ ' (with a RIR of 1.0000) is the most important and challenge ' $C_{2}$ ' (with a RIR of 0.0830 ) is the least important as compared to the other challenges. By using the preference rating approach, the final ranking of the considered challenges are as follows: $C_{4}>C_{5}>C_{6}>C_{7}>C_{1}>C_{3}>C_{2}$.

Figure 3 Importance rating by using preference rating approach (see online version for colours)

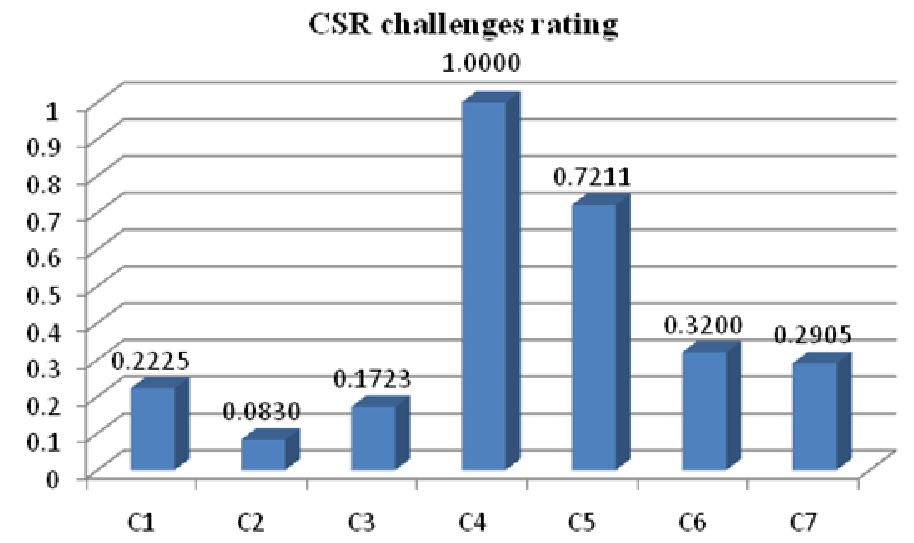

Table 5 Sum of influences given and received on challenges

\begin{tabular}{ccccc}
\hline & $D$ & $R$ & $D+R$ & $D-R$ \\
\hline$C_{1}$ & 2.5922 & 2.9334 & 5.5256 & -0.3411 \\
$C_{2}$ & 1.8445 & 2.9402 & 4.7847 & -1.0958 \\
$C_{3}$ & 2.2797 & 2.9120 & 5.1917 & -0.6323 \\
$C_{4}$ & 3.7014 & 2.6180 & 6.3194 & 1.0834 \\
$C_{5}$ & 3.4212 & 2.7438 & 6.1650 & 0.6774 \\
$C_{6}$ & 3.1276 & 2.8746 & 6.0022 & 0.2530 \\
$C_{7}$ & 2.8010 & 2.7456 & 5.5466 & 0.0554 \\
\hline
\end{tabular}

Further, the DEMATEL approach has been applied to validate these results. Table 5 gives the importance rating of CSR challenges on the basis of $(D+R)$ values, calculated from the DEMATEL approach. By using this approach, ranking order also comes as $C_{4}>$ $C_{5}>C_{6}>C_{7}>C_{1}>C_{3}>C_{2}$; graphical representation of the importance rating is shown in Figure 4. The comparison of results from both approaches is given in Figure 5, which provides evidence of validity of the results obtained by the CPR method. 
Figure 4 Importance rating by using DEMATEL approach (see online version for colours)

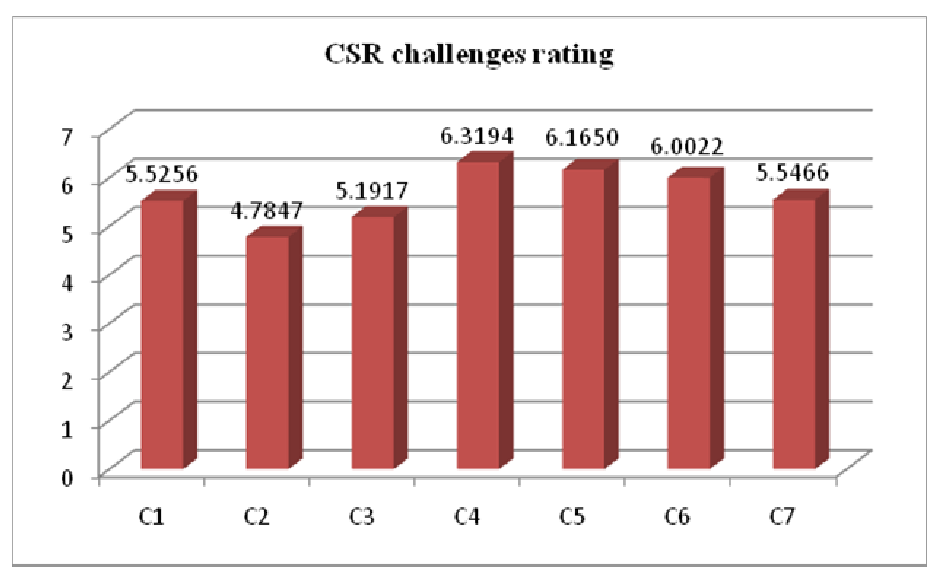

Figure 5 Comparison of importance rating (see online version for colours)

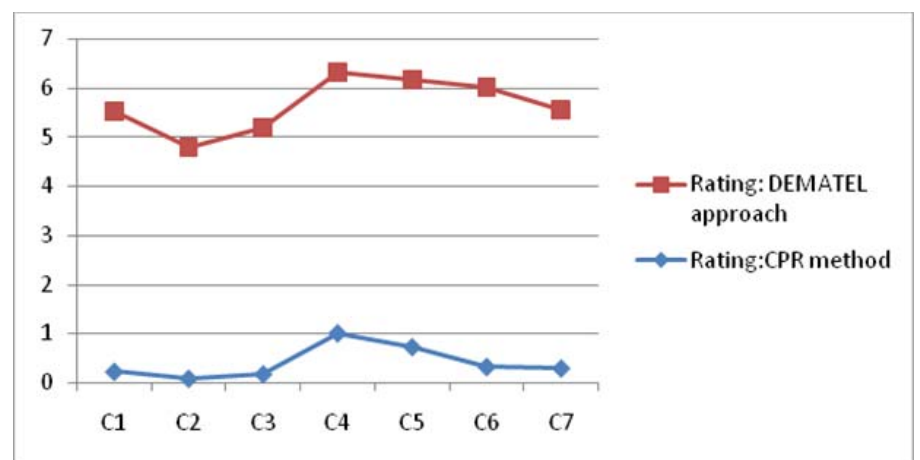

\section{Discussion and conclusions}

During this study, the CPR approach is used to find out the importance rating of the CSR challenges. Preference graphs are used to collect the uncertain opinions, to improve the SCP under CSR considerations, of the decision-makers. Each preference graph shows the interaction between the CSR challenges, given by a group of experts, of a particular company. On the basis of these four PGs, as shown in Figure 1, the RIR of the existing challenges, as given in equation (12), was computed. The result clearly shows that the 'narrow perception towards CSR initiatives' challenge attains the highest RIR and the 'lack of transparency' challenge attains the lowest RIR. The ranking of the seven challenges on the basis of the RIR is as follows: $C_{4}>C_{5}>C_{6}>C_{7}>C_{1}>C_{3}>C_{2}$.

The DEMATEL approach has been applied to check the validity of the RIR. It has been seen that the results obtained by the DEMATEL approach are similar to the results obtained by the preference rating approach. Figure 5 gives the clear view of comparison of these results. The categorisation of the CSR challenges has been made on the basis of the $(D-R)$ values as shown in Table 5 . The CSR challenges narrow perception towards 
CSR initiatives $\left(C_{4}\right)$, non-availability of clear CSR guidelines $\left(C_{5}\right)$, lack of consensus on implementing CSR issues $\left(C_{6}\right)$ and lack of thinking towards environmental protection $\left(C_{7}\right)$ have positive $(D-R)$ values and thus come under the category of the cause group. On the other side, challenges lack of awareness of local public in CSR activities $\left(C_{1}\right)$, lack of transparency $\left(C_{2}\right)$ and non-availability of well-organised non-governmental organisations $\left(C_{3}\right)$ have negative $(D-R)$ values; therefore, they comes under category of the effect group. The cause group challenges have an influence over the effect group challenges. It is noticed that the challenge $C_{4}$ has the highest RIR $(1.0000),(D+R)$ value (6.3194) and $(D-R)$ value (1.0834). Therefore, the challenge 'narrow perception towards CSR initiatives $\left(C_{4}\right)$ ' should be emphasised more towards improving the SCP of an organisation. Hence, cause group CSR challenges $\left(C_{4}, C_{5}, C_{6}\right.$ and $\left.C_{7}\right)$ play a significant role in achieving the specified objective and thus should be more emphasised as they have a high influencing nature. On the other hand, the effect group CSR challenges $\left(C_{1}, C_{2}\right.$ and $\left.C_{3}\right)$ can be influenced easily by the cause group challenges; therefore, they need to be improved to achieve an effective supply chain performance.

The findings of this research may help mangers in taking decisions and framing policies in the context of CSR for improving the SCP of their organisation effectively and efficiently. The limitation of the present study is that it represents only a limited geographic area of India, which is the NCR. Hence, it cannot be concluded that the results will be applicable for automobile industries located all over India. The limitation creates future directions for this research as other sectors instead of the automobile sector can also be considered for data collection and multi-criteria decision-making techniques can be used to find out the importance level of the CSR challenges.

\section{Acknowledgements}

The authors would like to express their sincere thanks to the editor-in-chief, Prof. Nelson K.Y. Leung, and the reviewers for their valuable suggestions and useful comments on the earlier version of this paper.

\section{References}

Afonso, S.C., Fernandes, P.O. and Monte, A.P. (2012) 'CSR of top Portuguese companies: relation between social performance and economic performance', World Academy of Science, Engineering and Technology, No. 66, pp.853-857.

Ageron, B., Gunasekaran, A. and Spalanzani, A. (2012) 'Sustainable supply management: an empirical study', International Journal of Production Economics, Vol. 140, No. 1, pp.168-182.

Azevedo, S.G., Govindan, K., Carvalho, H. and Cruz-Machado, V. (2013) 'Ecosilient index to assess the greenness and resilience of the upstream automotive supply chain', Journal of Cleaner Production, Vol. 56, No. 1, pp.131-146.

Basheka, B.C. and Serugo, F. (2011) 'Corporate social responsibility (CSR) initiatives in the telecommunications downstream supply chains: the case of MTN in Uganda', International Journal of Procurement Management, Vol. 4, No. 4, pp.402-418.

Bhattacharyya, S.S. (2010) 'Development of a scale on strategic corporate social responsibility constructs', International Journal of Indian Culture and Business Management, Vol. 3, No. 2, pp.181-207. 
Boyd, D.E., Spekman, R.E., Kamauff, J.W. and Werhane, P. (2007) 'Corporate Social responsibility in global supply chains: a procedural justice perspective', Long Range Planning, Vol. 40, No. 3, pp.341-356.

Carroll, A. (1999) 'Corporate social responsibility: evolution of a definitional construct', Business \& Society, Vol. 38, No. 3, pp.268-295.

Castka, P. and Balzarova, M.A (2008) 'ISO 26000 and supply chains: on the diffusion of the social responsibility standard', International Journal of Production Economics, Vol. 111, No. 2, pp.274-286.

Chapple, W., Paul, C.J.M. and Harris, R. (2005) 'Manufacturing and corporate environmental responsibility: cost implications of voluntary waste minimization', Structural Change and Economic Dynamics, Vol. 16, No. 3, pp.347-373.

Christmann, P. (2004) 'Multinational companies and the natural environment: determinants of global environmental policy standardization', Academy of Management Journal, Vol. 47, No. 5, pp.747-760.

Ciliberti, F., Pontrandolfo, P. and Scozzi, B. (2008) 'Investigating corporate social responsibility in supply chains: a SME perspective', Journal of Cleaner Production, Vol. 16, No. 15, pp.1579-1588.

Ciliberti, F., Haan, J.D., Groot, G.D. and Pontrandolfo, P. (2011) 'CSR codes and the principalagent problem in supply chains: four case studies', Journal of Cleaner Production, Vol. 19, No. 8, pp.885-894.

Font, X., Walmsley, A., Cogotti, S., McCombes, L. and Häusler, N. (2012) 'Corporate social responsibility: the disclosure-performance gap', Tourism Management, Vol. 33, No. 6, pp.1544-1553.

Fukukawa, K. and Teramoto, Y. (2009) 'Understanding Japanese CSR: the reflections of managers in the field of global operations', Journal of Business Ethics, Vol. 85 No. 1, pp.133-146.

Fuzi, N.M., Habidin, N.F., Desa, A.F.N.C., Zamri, F.I.M. and Hibadullah, S.N. (2013) 'Corporate social responsibility practices, ISO 26000 efforts and CSR performance in Malaysian automotive industry', International Journal of Managerial and Financial Accounting, Vol. 5, No. 3. pp.277-293.

Gelbmann, U. (2010) 'Comparative analysis of innovative CSR tools for SMEs', International Journal of Innovation and Sustainable Development, Vol. 5, No. 1, pp.35-50.

Gunningham, N. (2009) 'Shaping corporate environmental performance: a review', Environmental Policy and Governance, Vol. 19, No. 4, pp.215-231.

Heslin, P.A. and Ochoa, J.D. (2008) 'Understanding and developing strategic corporate social responsibility', Organizational Dynamics, Vol. 37, No. 2, pp.125-144.

Husted, B.W. and Salazar, J.D.J. (2006) 'Taking Friedman seriously: maximizing profits and social performance', Journal of Management Studies, Vol. 43, No. 1, pp.75-91.

Jamali, D. and Mirshak, R. (2007) 'Corporate social responsibility (CSR): theory and practice in a developing country context', Journal of Business Ethics, Vol. 72, No. 3, pp.243-262.

Jamali, D., Safieddine, A.M. and Rabbath, M. (2008) 'Corporate governance and corporate social responsibility synergies and interrelationships', Corporate Governance: An International Review, Vol. 16, No. 5, pp.443-459.

Khanna, P. and Gupta, G. (2011) 'Status of corporate social responsibility: in Indian context', Asia Pacific Journal of Research in Business Management, Vol. 2, No. 1, pp.178-187.

Knudsen, J.S. (2013) 'The integration of corporate social responsibility (CSR) initiatives into business activities: can lessons be learnt from gender diversity programmes?' International Journal of Business Governance and Ethics, Vol. 8, No. 3, pp.210-223.

Lee, M.D.P. (2008) 'A review of the theories of corporate social responsibility: its evolutionary path and the road ahead', International Journal of Management Reviews, Vol. 10, No. 1, pp.53-73.

Lial, M.L., Greenwell, R.N. and Ritchey, N.P. (2002) Finite Mathematics, Addison Wesley, New York. 
Lindgreen, A., Swaen, V. and Johnston, W.J. (2009) 'Corporate social responsibility: an empirical investigation of US organizations', Journal of Business Ethics, Vol. 85, No. 2, pp.303-323.

Loureiro, S.M.C., Sardinha, I.M.D. and Reijnders, L. (2012) 'The effect of corporate social responsibility dimensions on consumer satisfaction and perceived value: the case of the automobile sector in Portugal', Journal of Cleaner Production, Vol. 37, pp.172-178.

Luo, X. and Bhattacharya, C.B. (2006) 'Corporate social responsibility, customer satisfaction and market value', Journal of Marketing, Vol. 70, No. 4, pp.1-18.

Magnan, G.M., Fawcett, S.E., Alcantar, T.N. and Henshaw, K. (2011) 'On supply chains and reputation risk: tracking changes in supplier codes of conduct', International Journal of Procurement Management, Vol. 4, No. 6, pp.567-588.

Malhotra, M.K. and Grover, V. (1998) 'An assessment of survey research in POM: from constructs to theory', Journal of Operations Management, Vol. 16, No. 4, pp.407-425.

Maloni, M.J. and Brown, M.E. (2006) 'Corporate social responsibility in the supply chain: an application in the food industry', Journal of Business Ethics, Vol. 68, No. 1, pp.35-52.

McWilliams, A. and Siegel, D. (2000) 'Corporate social responsibility and financial performance: correlation or misspecification?’ Strategic Management Journal, Vol. 21, No. 5, pp.603-609.

Mishra, S. (2012) 'Exploring the impact of corporate social responsibility on consumer behaviour in India', International Journal of Business Innovation and Research, Vol. 6, No. 4, pp.401-417.

Murillo, D. and Lozano, J.M. (2006) 'SMEs and CSR: an approach to CSR in their own words', Journal of Business Ethics, Vol. 67, No. 3, pp.227-240.

Nahm, Y.E. and Ishikawa, H. (2005) 'Representing and aggregating engineering quantities with preference structure for set-based concurrent engineering', Concurrent Engineering: Research Application, Vol. 13, No. 2, pp.123-133.

Nahm, Y.E. and Ishikawa, H. (2006) 'A new 3D-CAD system for set-based parametric design', International Journal of Advanced Manufacturing Technology, Vol. 29, Nos. 1-2, pp.137-150.

Nahm, Y.E., Ishikawa, H. and Inoue, M. (2013) 'New rating methods to prioritize customer requirements in QFD with incomplete customer preferences', International Journal of Advanced Manufacturing Technology, Vol. 65, Nos. 9-12, pp.1587-1604.

Porter, M.E. and Kramer, M. (2002) 'The competitive advantage of corporate philanthropy', Harvard Business Review, Vol. 80, No. 12, pp.56-68.

Porter, M.E. and Kramer, M. (2006) 'Strategy and society: the link between competitive advantage and corporate social responsibility', Harvard Business Review, Vo. 84, No. 12, pp.78-92.

Risso, M. (2012) 'A horizontal approach to implementing corporate social responsibility in international supply chains', International Journal of Technology Management, Vol. 58, Nos. 1-2, pp.64-82.

Saad, M. and Patel, B. (2006) 'An investigation of supply chain performance measurement in Indian automotive sector', Benchmarking: An International Journal, Vol. 13, Nos. 1-2, pp.36-53.

Sardinha, I.D., Reijnders, L. and Antunes, P. (2011) 'Using corporate social responsibility benchmarking framework to identify and assess corporate social responsibility trends of real estate companies owning and developing shopping centres', Journal of Cleaner Production, Vol. 19, No. 13, pp.1486-1493.

Seuring, S. and Müller, M. (2008) 'Core issues in sustainable supply chain management: a Delphi study', Business Strategy and the Environment, Vol. 17, No. 8, pp.455-466.

Spena, T.R. and De Chiara, A. (2012) 'CSR, innovation strategy and supply chain management: toward an integrated perspective', International Journal of Technology Management, Vol. 58, Nos. 1-2, pp.83-108.

Svendsen, A., Boutilier, R.G., Abbott, R.M. and Wheeler, D. (2001) 'Measuring the business value of stakeholder relationships (part one)', CA Magazine, August, pp.29-63. 
Tsiakis, T. (2009) 'Contribution of corporate social responsibility to information security management', Information Security Technical Report, Vol. 14, No. 4, pp.217-222.

Tzeng, G.H., Chiang, C.H. and Li, C.W. (2007) 'Evaluating intertwined effects in e-learning programs: a novel hybrid MCDM model based on factor analysis and DEMATEL', Expert Systems with Applications, Vol. 32, No. 4, pp.1028-1044.

Valiente, J.M.A., Ayerbe, C.G. and Figueras, M.S. (2012) 'Social responsibility practices and evaluation of corporate social performance', Journal of Cleaner Production, Vol. 35, pp. $25-38$.

Vicianova, J. (2011) 'Corporate social responsibility in the automobile industry in Slovak Republic', Studia Universitatis Vasile Goldiş Arad-Seria Ştiințe Economice, Vol. 1, No. 1, pp.192-201.

Whatling, D.R., Hedges, P., Brown, R. and Fermor, P. (2010) 'Corporate responsibility reporting of biodiversity in the supply chain', International Journal of Innovation and Sustainable Development, Vol. 5, No. 1, pp.51-64.

Wu, W.W. (2008) 'Choosing knowledge management strategies by using a combined ANP and DEMATEL approach', Expert Systems with Applications, Vol. 35, No. 3, pp.828-835.

Yilmaz, A.K. (2008) 'The corporate social responsibility practice in the Turkish automotive distribution companies', International Journal of Business and Management, Vol. 3, No. 6, pp.139-147. 